\title{
Assessment of pH of Calcium Silicate Based Root Canal Sealers at Various Time Periods - an In Vitro Study
}

\author{
Murthi Meenapriya'and Raghu Sandhya² \\ ${ }^{1}$ Saveetha Dental College and Hospitals, Saveetha Institute of Medical and Technical \\ Sciences,Saveetha University, Chennai - 600077 Tamilnadu, India. \\ ${ }^{2}$ Reader, Department of Conservative Dentistry and Endodontics, Saveetha Dental College and Hospitals, Saveetha \\ Institute of Medical and Technical Sciences, Saveetha University, Chennai - 600 077, Tamilnadu, India
}

\section{ABSTRACT}

Calcium silicate sealers otherwise known as the bioceramic sealers were introduced into dentistry as an alternative root canal sealer. This material originally came from the combination of calcium silicate and calcium phosphate. Calcium phosphate enhances the setting properties resulting in a chemical composition and crystalline structure similar to tooth and bone apatite materials, thereby improving the sealer to root-dentin bonding. Comparison of the physicochemical and biological properties of bio ceramic sealers with the conventional sealers reveals that the calcium silicate based sealers are similar or better. Therefore, the aim of this study is to assess the $\mathrm{pH}$ of calcium silicate based root canal sealer at various time periods. Commercial brand of calcium silicate sealer [Bioroot RCS, Septodont] was used for this study. To determine $\mathrm{pH}, 3$ samples were prepared and introduced into polyethylene tubes. Each sample was placed in a tube containing $10 \mathrm{ml}$ of distilled water and stored at 37 degree C. $\mathrm{pH}$ assessment was performed after $1 \mathrm{hr}, 3 \mathrm{hr}, 24 \mathrm{hr}, 48 \mathrm{hr}, 120 \mathrm{hr}, 168 \mathrm{hr}, 192 \mathrm{hrs}, 28$ days after immersion. The samples were assessed for $\mathrm{pH}$ using the digital $\mathrm{pH}$ meter. The control for the method was based on the reading of $\mathrm{pH}$ values of distilled water in which no samples were immersed. Descriptive analysis of the values was performed. The $\mathrm{pH}$ of calcium silicate based root canal sealer at various time periods was $11.1 \mathrm{at} 1 \mathrm{hr}, 11.5$ at $3 \mathrm{hrs}, 11.9$ at $24 \mathrm{hrs}, 11.9$ at $48 \mathrm{hrs}$, 12.3 at $120 \mathrm{hrs}, 12.2$ at $168 \mathrm{hrs}, 12.0$ at $192 \mathrm{hrs}, 11.9$ at 28 days. The $\mathrm{pH}$ of the distilled water in which no samples were immersed was found to be 7.04. Bioroot RCS calcium silicate based sealer had alkaline pH. High alkaline $\mathrm{pH}$ of the sealer assumes particular importance because it enhances the deposition of hard tissue, improving the antibacterial properties by the release of calcium ions. Clinical trials and long term follow up studies would be highly valuable to evaluate the bio ceramic sealer's clinical performance.

\section{KEY WORDS: BIO CERAMIC SEALERS, CALCIUM SILICATE, PH, TIME PERIODS, ALKALINITY.}

\section{INTRODUCTION}

Endodontic sealers are used to attain a fluid-proof seal throughout the root canal system. An ideal root canal

\section{ARTICLE INFORMATION}

*Corresponding Author: sandhya.sdc@saveetha.com Received 15th June 2020 Accepted after revision 4th August 2020 Print ISSN: 0974-6455 Online ISSN: 2321-4007 CODEN: BBRCBA

Thomson Reuters ISI Web of Science Clarivate Analytics USA and Crossref Indexed Journal

\section{Clarivate}

NAAS Journal Score 2020 (4.31) SJIF: 2020 (7.728)

A Society of Science and Nature Publication,

Bhopal India 2020. All rights reserved.

Online Contents Available at: http//www.bbrc.in/

Doi: http://dx.doi.org/10.21786/bbrc/13.7/48 sealer should offer an excellent seal when set, dimensional stability, a sufficient setting time to ensure working time, insolubility against tissue fluids, proper adhesion with canal walls, and biocompatibility. (Lee et al., 2017) The commercially available sealers are categorized as zinc-oxide eugenol, calcium hydroxide containing, resin-based, glass-ionomer based, silicone-based, and bio ceramic-based sealers.

Calcium silicate-based sealers are usually known as bio ceramic sealers and introduced to dentistry as an alternative endodontic sealer. This material originally 
came from a combination of calcium silicate and calcium phosphate. Calcium phosphate enhances the setting properties of bioceramic sealers resulting in a chemical composition and crystalline structure similar to the tooth and bone apatite materials, thereby improving sealer-toroot dentin bonding. (Mendes et al., 2018).

Root end filling materials should possess certain properties such as their own good sealing ability, improve the seal of existing root canal filling material, and should be biocompatible with the periradicular tissues. The root end filling material should also have the ability to increase the $\mathrm{pH}$ and release of calcium ions $(\mathrm{Ca}++)$ as it leads to mineralized tissue formation. (Kumari et al., 2018)

Calcium based sealers were used due to their antimicrobial activity owing to their $\mathrm{Ca}++$ releasing potential. These sealers have been popularly used because of their potential for providing a high alkaline environment. The use of these materials highly aids in mineralization of hard tissue and provides good antimicrobial activity. (Shashank et al., 2019) Alka-line pH could neutralize the lactic acid from osteoclasts and prevent dissolution of minera-lized components of teeth. (Poggio et al., 2017)

We have numerous highly cited publications on well designed clinical trials and lab studies (Govindaraju, Neelakantan and Gutmann, 2017; Azeem and Sureshbabu, 2018; Jenarthanan and Subbarao, 2018; Manohar and Sharma, 2018; Nandakumar and Nasim, 2018; Teja,
Ramesh and Priya, 2018; Janani and Sandhya, 2019; Khandelwal and Palanivelu, 2019; Malli Sureshbabu et al., 2019; Poorni, Srinivasan and Nivedhitha, 2019; Rajakeerthi and Ms, 2019; Rajendran et al., 2019; Ramarao and Sathyanarayanan, 2019; Siddique and Nivedhitha, 2019; Siddique et al., 2019; Siddique, Nivedhitha and Jacob, 2019). This has provided the right platforms for us to pursue the current study. Therefore, this study aims at the assessment of $\mathrm{pH}$ of a calcium silicate based root canal sealers [Bioroot RCS Septodont] at various time periods.

\section{MATERIAL AND METHODS}

One commercial brand of bio ceramic sealer [Bioroot RCS Septodont] was tested. To determine the $\mathrm{pH}$ of calcium silicate based root canal sealer, 3 samples were prepared. The samples were prepared by mixing the powder and liquid in smooth consistency. The mixed sealer was introduced into the sample of dimensions $1 \mathrm{~mm}$ height and $1 \mathrm{~mm}$ diameter. These samples were placed in a tube containing $10 \mathrm{ml}$ of distilled water. One tube containing $10 \mathrm{ml}$ of distilled water without any sealer was used as the control. All the samples are placed inside the incubator at 37 degree $\mathrm{C}$ at the room temperature.

The $\mathrm{pH}$ measurements were done after $1 \mathrm{hr}, 3 \mathrm{hr}, 24 \mathrm{hr}$, 48hrs, 120hrs, 168hrs and 192hrs, 28 days of immersion. The $\mathrm{pH}$ of each sample was measured in a digital $\mathrm{pH}$ meter. (Leonardo et al., 2013) The readings were noted and tabulated. [Table 1]

Table 1. This table shows the $\mathrm{pH}$ of calcium silicate sealer [Bioroot RCS Septodont] at various time periods.

\begin{tabular}{|l|c|c|c|c|c|c|c|c|}
\hline SAMPLE & $\begin{array}{c}\mathrm{pH} \\
\text { after 1 hr }\end{array}$ & $\begin{array}{c}\mathrm{pH} \\
\text { after 3hr }\end{array}$ & $\begin{array}{c}\mathrm{pH} \\
\text { after 24hr }\end{array}$ & $\begin{array}{c}\mathrm{pH} \\
\text { after 48hr }\end{array}$ & $\begin{array}{c}\mathrm{pH} \\
\text { after 120hr } \\
\text { /5 days }\end{array}$ & $\begin{array}{c}\mathrm{pH} \\
\text { after 168hr } \\
\text { /7 days }\end{array}$ & $\begin{array}{c}\mathrm{pH} \\
\text { after 192hr } \\
\text { /8days }\end{array}$ & $\begin{array}{c}\mathrm{pH} \\
\text { after } \\
28 \text { days }\end{array}$ \\
\hline DISTILLED WATER & 6.8 & 7 & 7 & 7 & 7.2 & 7.29 & 7 & 7 \\
\hline 1ST SAMPLE & 11.2 & 11.5 & 11.9 & 12 & 12.4 & 12.3 & 12 & 11.8 \\
\hline 2nd SAMPLE & 11.1 & 11.5 & 11.9 & 12 & 12.3 & 12.2 & 12 & 12 \\
\hline 3rd SAMPLE & 11.1 & 11.6 & 11.9 & 11.9 & 12.3 & 12.2 & 12 & 12 \\
\hline
\end{tabular}

\section{RESULTS AND DISCUSSION}

The $\mathrm{pH}$ of the bioceramic root canal sealer used \{Bioroot RCS Septodont] at different time periods of $1 \mathrm{hr}, 3 \mathrm{hr}$, $24 \mathrm{hr}, 48 \mathrm{hr}, 120 \mathrm{hrs}, 168 \mathrm{hr}, 192 \mathrm{hrs}, 28$ days were noted and tabulated as follows: [Table 1] [Figure 1]

The results revealed that the $\mathrm{pH}$ of the calcium silicate based root canal sealer [Bioroot RCS Septodont] was 11.1 at $1 \mathrm{hr}, 11.5$ at $3 \mathrm{hrs}, 11.9$ at $24 \mathrm{hrs}, 11.9$ at $48 \mathrm{hrs}, 12.3$ at $120 \mathrm{hrs}, 12.2$ at $168 \mathrm{hrs}, 12.0$ at $192 \mathrm{hrs}, 11.9$ at 28 days. This shows that the $\mathrm{pH}$ constantly increases with the increasing time periods till 5 days. Remains above 12 until 168 hrs. Remains at pH 12 at 192 hrs and 28 days [Table 1, Figure 1].
Bio ceramics are specifically designed for medical and dental use with the prefix 'bio' referring to their biocompatibility. The active bio ceramics and reabsorbable ones are applied in the endodontic field. They are composed of alumina, zirconia, bioactive glass, glass ceramics, coatings, composites, hydroxyapatite, resorbable calcium phosphates and radiotherapy glasses. Calcium silicates and bio-aggregates (Mineral Trioxide Aggregate for example) are used for apical plug in apexification procedures but also for coronal/root repair in case of perforations.

Sterilizing and obtaining a root canal free of bacteria, following disinfection is impossible to obtain. Apart from disinfecting, the obturation plays an important role to trap residual bacteria, fill the pre-disinfected space and 
ultimately seal it, in order to avoid any bacterial leakage into the periapical area. Modern techniques for filling the root canals are based on the association of gutta percha (the core of the filling) and a sealer. The latter acts as a sealing material and, because of its fluidity, it is able to spread into any free space, notably those which were not enlarged during the mechanical root canal preparation. (Marchi, Scheire and Simon, 2020).

Figure 1: Figure showing the simple scatter plot of the $\mathrm{pH}$ of distilled water and the calcium silicate sealer. Here, $\mathrm{X}$ axis shows the time at which $\mathrm{pH}$ was assessed and $\mathrm{Y}$ axis represents the $\mathrm{pH}$ of distilled water (blue line) and the calcium silicate sealer (red line). The $\mathrm{pH}$ of the calcium silicate sealer increased gradually with time and remained around 12 after a specified time. Similarly the $\mathrm{pH}$ of the distilled water remained around 7 over the time analysed. Chi square analysis showed that the variation in the $\mathrm{pH}$ of the distilled water and calcium silicate sealer was statistically not significant [Pearson's chi-square test; $p$ $>0.05$ - statistically not significant]. Though statistically not significant, this minimal increase in the $\mathrm{pH}$ may be clinically significant.

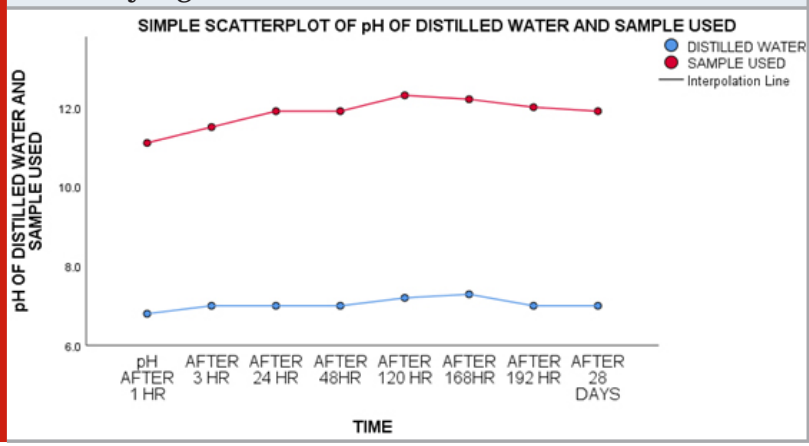

This study evaluated the $\mathrm{pH}$ of the calcium silicate sealers at various time periods. The calcium silicate based root canal sealers revealed that the $\mathrm{pH}$ increases with increasing time periods after the setting time and there is stable $\mathrm{pH}$ after $168 \mathrm{hrs}$ of immersion. This high alkaline $\mathrm{pH}$ promotes elimination of bacteria such as Enterococcus faecalis that might survive after chemo mechanical preparation and induce or maintain periapical inflammation. The mechanism of repair stimulation by deposition of mineralized tissue depends on $\mathrm{pH}$ and on the ability to release $\mathrm{Ca} 2+$ and water. (Candeiro et al., 2012).

MTA Fill Apex and AH Plus promoted an alkaline $\mathrm{pH}$ when immersed in distilled water, with values ranging from 7.30 to 11.35 , which remained high until the end of the experiment. MTA-based cements are rich in calcium ions, which are converted to calcium hydroxide upon contact with the water, and dissociate into calcium and hydroxyl ions, increasing $\mathrm{pH}$ of the solution. Thus, the variation in the concentration of calcium hydroxide leads to different $\mathrm{pH}$ values. A high $\mathrm{pH}$ activates alkaline phosphatase, an enzyme strictly involved in the mineralization process and also neutralizes the acids secreted by osteoclasts, avoiding the destruction of mineralized tissue. (Borges et al., 2014) (Silva et al., 2003) (Jafari and Jafari, 2017) (Schäfer and Zandbiglari, 2003).

Literature search reveals various reports on the antimicrobial activity of calcium hydroxide based sealers. (Muniti冈 et al., 2019) It is quite familiar that the $\mathrm{pH}$ values above 12 inhibit the growth of many microorganisms, including E. faecalis. Limited antibacterial efficacy against $\mathrm{E}$. faecalis for calcium hydroxide based sealers which have $\mathrm{pH}$ beyond 12, exhibits the inefficiency of calcium hydroxide based sealers. Extremely high $\mathrm{pH}$ value was not sufficient and that apart from it, some other factors also interfere with bacterial growth. (Geetha and Veeraraghavan, 2016) Previous reports showed that BC sealer exhibited an immediate, potent antibacterial effect up to $24 \mathrm{~h}$ after setting. However, its antibacterial effect considerably decreased within 3 days and was completely diminished at 7 days. This is in agreement to the result of an in vitro study that reported a short antibacterial action of $\mathrm{BC}$ sealer against $\mathrm{E}$. faecalis. (Trisic et al., 2019) (Chotvorrarak et al., 2017)

In the study conducted for the fracture resistance of roots filled with various root canal sealers, the Bioceramic sealers showed the highest fracture resistance. Physicochemical properties of MTA Plus sealer such as calcium ion release, hydration reaction and $\mathrm{pH}$ did not change when powder was mixed either with water or gel. (Uzunoglu Ozyurek and Aktemur Turker, 2019) In the study conducted for assessing the biocompatibility, calcium silicate-based sealers showed decreased cell viability by time in fresh media, which might be a result of their high $\mathrm{pH}$ in the fresh state. Although the high $\mathrm{pH}$ of root canal sealers might have this negative effect on cell viability, it may provide several biological advantages. (Lim et al., 2015) (Lee et al., 2019) (Alsubait et al., 2018) $\mathrm{pH}$ of calcium silicate based root canal sealer [Bioroot RCS Septodont] were higher than the other root canal sealers evaluated in the previous studies. (Zhou et al., 2013) (Duarte et al., 2003) However, the high solubility of the calcium silicate sealers needs to be studied further.

\section{CONCLUSION}

Within the limitations of this study, $\mathrm{pH}$ of the calcium silicate sealer [Bioroot RCS Septodont] was found to be 11.1 at $1 \mathrm{hr}, 11.5$ at $3 \mathrm{hrs}, 11.9$ at $24 \mathrm{hrs}, 11.9$ at $48 \mathrm{hrs}$, 12.3 at $120 \mathrm{hrs}, 12.2$ at $168 \mathrm{hrs}, 12.0$ at $192 \mathrm{hrs}, 11.9$ at 28 days.

\section{ACKNOWLEDGEMENTS}

This study was supported by Saveetha Dental College and Hospitals, Saveetha Institute of Medical and Technical Sciences, Saveetha University, Chennai.

Conflict of Interest: There were no conflicts of interest as declared by the authors. 


\section{REFERENCES}

Alsubait, S. et al. (2018) 'Cytotoxicity of Different Concentrations of Three Root Canal Sealers on Human Mesenchymal Stem Cells', Biomolecules, p. 68. doi: 10.3390/biom8030068.

Azeem, R. A. and Sureshbabu, N. M. (2018) 'Clinical performance of direct versus indirect composite restorations in posterior teeth: A systematic review', Journal of conservative dentistry: JCD, 21(1), pp. 2-9. Borges, Á. H. et al. (2014) 'Physicochemical Properties and Surfaces Morphologies Evaluation of MTA FillApex and AH Plus', The Scientific World Journal, pp. 1-6. doi: $10.1155 / 2014 / 589732$.

Candeiro, G. T. de M. et al. (2012) 'Evaluation of Radiopacity, pH, Release of Calcium Ions, and Flow of a Bioceramic Root Canal Sealer', Journal of endodontics, 38(6), pp. 842-845.

Chotvorrarak, K. et al. (2017) 'In vitro antibacterial activity of oligomer-based and calcium silicate-based root canal sealers', literatures, 4, p. 5.

Duarte, M. A. H. et al. (2003) ' $\mathrm{pH}$ and calcium ion release of 2 root-end filling materials', Oral surgery, oral medicine, oral pathology, oral radiology, and endodontics, 95(3), pp. 345-347.

Geetha, R. V. and Veeraraghavan, V. P. (2016) 'Evaluation of antibacterial activity of five root canal sealants against enterococcus faecalis-an in vitro study', Int J Pharm Sci Rev Res, 40, pp. 221-223.

Govindaraju, L., Neelakantan, P. and Gutmann, J. L. (2017) 'Effect of root canal irrigating solutions on the compressive strength of tricalcium silicate cements', Clinical oral investigations, 21(2), pp. 567-571.

Jafari, F. and Jafari, S. (2017) 'Composition and physicochemical properties of calcium silicate based sealers: A review article', Journal of Clinical and Experimental Dentistry, pp. e1249-e1255. doi: 10.4317/ jced.54103.

Janani, K. and Sandhya, R. (2019) 'A survey on skills for cone beam computed tomography interpretation among endodontists for endodontic treatment procedure', Indian journal of dental research: official publication of Indian Society for Dental Research, 30(6), pp. 834-838.

Jenarthanan, S. and Subbarao, C. (2018) 'Comparative evaluation of the efficacy of diclofenac sodium administered using different delivery routes in the management of endodontic pain: A randomized controlled clinical trial', Journal of conservative dentistry: JCD, 21(3), pp. 297-301.

Khandelwal, A. and Palanivelu, A. (2019) 'Correlation Between Dental Caries And Salivary Albumin In Adult Population In Chennai: An In Vivo Study', Brazilian
Dental Science, 22(2), pp. 228-233.

Kumari, S. et al. (2018) 'Comparative evaluation of physical and chemical properties of calcium silicatebased root-end filling materials (Mineral trioxide aggregate and biodentine): An in vitro study', Indian Journal of Dental Sciences. Medknow Publications, 10(4), p. 197.

Lee, J. K. et al. (2017) 'Physicochemical Properties of Epoxy Resin-Based and Bioceramic-Based Root Canal Sealers', Bioinorganic chemistry and applications, 2017, p. 2582849 .

Lee, J. K. et al. (2019) 'In Vitro Comparison of Biocompatibility of Calcium Silicate-Based Root Canal Sealers', Materials, p. 2411. doi: 10.3390/ma12152411. Leonardo, R. de T. et al. (2013) 'Evaluation of the Physicochemical Properties and Push- Out Bond Strength of Mta-based Root Canal Cement', The Journal of Contemporary Dental Practice, pp. 1094-1099. doi: 10.5005/jp-journals-10024-1457.

Lim, E.-S. et al. (2015) 'Physical properties and biocompatibility of an injectable calcium-silicate-based root canal sealer: in vitro and in vivo study', BMC oral health, 15(1), p. 129.

Malli Sureshbabu, N. et al. (2019) 'Concentrated Growth Factors as an Ingenious Biomaterial in Regeneration of Bony Defects after Periapical Surgery: A Report of Two Cases', Case reports in dentistry, 2019, p. 7046203.

Manohar, M. P. and Sharma, S. (2018) 'A survey of the knowledge, attitude, and awareness about the principal choice of intracanal medicaments among the general dental practitioners and nonendodontic specialists', Indian journal of dental research: official publication of Indian Society for Dental Research, 29(6), pp. 716-720.

Marchi, V., Scheire, J. and Simon, S. (2020) 'Retreatment of Root Canals Filled with BioRoot RCS: An In Vitro Experimental Study', Journal of Endodontics, pp. 858-862. doi: 10.1016/j.joen.2020.03.018.

Mendes, A. T. et al. (2018) 'Evaluation of Physicochemical Properties of New Calcium Silicate-Based Sealer', Brazilian Dental Journal, pp. 536-540. doi: 10.1590/01036440201802088.

Munitic, M. Š. et al. (2019) 'Antimicrobial efficacy of commercially available endodontic bioceramic root canal sealers: A systematic review', PLOS ONE, p. e0223575. doi: 10.1371/journal.pone.0223575.

Nandakumar, M. and Nasim, I. (2018) 'Comparative evaluation of grape seed and cranberry extracts in preventing enamel erosion: An optical emission spectrometric analysis', Journal of conservative dentistry: JCD, 21(5), pp. 516-520.

Poggio, C. et al. (2017) 'Solubility and pH of bioceramic root canal sealers: A comparative study', Journal of 
clinical and experimental dentistry, 9(10), pp. e1189e1194.

Poorni, S., Srinivasan, M. R. and Nivedhitha, M. S. (2019) 'Probiotic strains in caries prevention: A systematic review', Journal of conservative dentistry: JCD, 22(2), pp. 123-128.

Rajakeerthi, R. and Ms, N. (2019) 'Natural Product as the Storage medium for an avulsed tooth - A Systematic Review', Cumhuriyet Dental Journal, 22(2), pp. 249256.

Rajendran, R. et al. (2019) 'Comparative Evaluation of Remineralizing Potential of a Paste Containing Bioactive Glass and a Topical Cream Containing Casein Phosphopeptide-Amorphous Calcium Phosphate: An in Vitro Study', Pesquisa brasileira em odontopediatria e clinica integrada, 19(1), pp. 1-10.

Ramarao, S. and Sathyanarayanan, U. (2019) 'CRA Grid - A preliminary development and calibration of a paper-based objectivization of caries risk assessment in undergraduate dental education', Journal of conservative dentistry: JCD, 22(2), pp. 185-190.

Schäfer, E. and Zandbiglari, T. (2003) 'Solubility of rootcanal sealers in water and artificial saliva', International endodontic journal, 36(10), pp. 660-669.

Shashank, S. et al. (2019) 'Comparative pH and calcium ion release in newer calcium silicate-based root canal sealers', Endodontology. Medknow Publications and Media Pvt. Ltd., 31(1), p. 29.

Siddique, R. et al. (2019) 'Qualitative and quantitative analysis of precipitate formation following interaction of chlorhexidine with sodium hypochlorite, neem, and tulsi', Journal of conservative dentistry: JCD, 22(1), pp. 40-47.

Siddique, R. and Nivedhitha, M. S. (2019) 'Effectiveness of rotary and reciprocating systems on microbial reduction: A systematic review', Journal of conservative dentistry: JCD, 22(2), pp. 114-122.

Siddique, R., Nivedhitha, M. S. and Jacob, B. (2019) 'Quantitative analysis for detection of toxic elements in various irrigants, their combination (precipitate), and para-chloroaniline: An inductively coupled plasma mass spectrometry study', Journal of conservative dentistry: JCD, 22(4), pp. 344-350.

Silva, L. A. B. et al. (2003) 'Calcium hydroxide root canal sealers: evaluation of $\mathrm{pH}$, calcium ion concentration and conductivity', International Endodontic Journal, pp. 205-209. doi: 10.1046/j.1365-2591.1997.00079.x.

Teja, K. V., Ramesh, S. and Priya, V. (2018) 'Regulation of matrix metalloproteinase-3 gene expression in inflammation: A molecular study', Journal of conservative dentistry: JCD, 21(6), pp. 592-596.

Trisic, D. et al. (2019) 'Antibacterial effects of new endodontic materials based on calcium silicates', Vojnosanitetski pregled, pp. 365-372. doi: 10.2298/ vsp161231130t.

Uzunoglu Ozyurek, E. and Aktemur Turker, S. (2019) 'Evaluation of fracture resistance of roots-filled with various root canal sealers at different time periods', European oral research, 53(1), pp. 6-11.

Zhou, H.-M. et al. (2013) 'Physical Properties of 5 Root Canal Sealers', Journal of Endodontics, pp. 1281-1286. doi: 10.1016/j.joen.2013.06.012. 